interest in effective judicial administration. Choosing the former would mean application of the traditional equity rule by the Supreme Court; ${ }^{66}$ choosing the latter would allow the states to apply Mineworkers. ${ }^{67}$ The Supreme Court may have made the latter choice in denying certiorari in Aladdin ${ }^{68}$ and Bogle v. Jakes Foundry. ${ }^{69}$ If the decision is yet to be made, it is submitted that the potential effect of the enforcement of state injunctions upon federal labor relations policy is sufficient both to render the decision a matter of federal law and to warrant that the federal courts adopt the traditional equity rule in regard to such injunctions.

${ }^{65}$ See note 3 supra. Although this is the course of action most favorable to the employees, it is not an ideal solution from their point of view either. First, they would be forced to risk incurring substantial fines and imprisonment in following their own evaluation of the state court's power to act. Secondly, disobedience would not be available as a means of neutralizing a state court injunction issued without jurisdiction should the state government elect to enforce its temporary decree through direct police action-such as arresting and confining strikers-rather than through initiating contempt actions in the courts.

${ }^{87}$ See notes 4-6 supra, and accompanying text.

68 361 U.S. 865 (1959).

69362 U.S. 401 (1960).

\title{
USE OF STATE STATUTES BY FEDERAI DISTRICT COURTS IN EXTRATERRITORIAL SERVICE OF PROCESS
}

In Kappus v. Western Hills Oil, Inc., a federal district court interpreted Rule 4(d)(7) of the Federal Rules of Civil Procedure ${ }^{2}$ as authorizing use of a state statute providing for extraterritorial service of process upon a nonresident defendant. ${ }^{3}$ Rule 4(d)(7) provides that it is "sufficient if the summons and complaint are served ... in the manner prescribed by the law of the state in which service is made for the service of summons [or] other like process upon any such defendant in an action brought in the courts of general jurisdiction of that state." Prior opinions have stated that 4(d)(7) must be interpreted as authoriz-

124 F.R.D. 123 (E.D. Wis. 1959).

2 Congress has delegated the rule making power to the Supreme Court. 28 U.S.C. $\S 2072$ (1958).

${ }^{3}$ There has been considerable discord in the federal courts as to the situations in which extraterritorial service is authorized by the Rules. Compare Farr v. Cia. Intercontinental De Navegacio de Cuba, 243 F.2d 342 (2d Cir. 1957), and Giffin v. Ensign, 234 F.2d 307 (3d Cir. 1956), and Hellriegel v. Sears, Roebuck \& Co., 157 F. Supp. 718 (N.D. Ill. 1957), with Heiser Ready Mix Co. v. Fenton, 265 F.2d 277 (7th Cir. 1959) and Pasternack v. Dalo, 17 F.R.D. 420 (W.D. Pa. 1955), and Johnson v. Scarborough, 88 F. Supp. 523 (S.D. Tex. 1949).

1 "[T] he law of the state in which service is made" might conceivably be read to mean that the law which governs service is that of the state in which the defendant receives notice of the action, rather than the state from which service emanates. Such a construction would have absurd results in that each district court would be empowered to serve nationwide process, conforming only to the state statute providing for intrastate personal service in whatever state the defendant might be found. Although the language of the Rule is inherently ambiguous, the Rule makes sense only if the state law referred to is that of the state in which the district court sits. No court has made a contrary interpretation. 
ing use of state statutes only for intrastate service because of the prohibition in Rule 4(f) that service may be made only "within the territorial limits of the state in which the district court is held...."

The consequence of this restrictive interpretation of Rule 4(d)(7) was avoided in Holbrook v. Cafiero, ${ }^{6}$ where it was decided that substituted service ${ }^{7}$ upon an official of the state from which service emanates would enable the court to obtain jurisdiction over a nonresident defendant. ${ }^{8}$ In Kappus the conflict between the opposing points of view was presented in its most fundamental form, since the state statute in question, having eliminated substituted service, ${ }^{9}$ prevented reliance upon Holbrook. ${ }^{10}$

Those who maintain that Rule 4(f) limits the application of Rule 4(d)(7) contend that their position does not violate the doctrine that all parts of a statute are to be construed in pari materia, ${ }^{11}$ since each rule supposedly has its

${ }^{5}$ McCoy v. Siler, 205 F.2d 498, 501 (3rd Cir. 1953) (concurring opinion of Maris, J.); Nemiec v. Interstate Motor Freight System, 2 F.R.D. 408 (W.D. Mich. 1942).

618 F. R.D 218 (D. Md. 1955).

7In this comment "substituted service" will refer only to the procedure by which process is served on an official of the state in which suit is brought with notice subsequently being sent to the nonresident defendant.

8 "The wording of the statute clearly shows that the service is made on the Secretary of State and, of course, must be within the state." That the state official subsequently notifies the defendant by registered mail of the service of process is a procedure necessary only to "conform ... to the federal constitutional provision requiring due process...." Holbrook v. Cafiero, 18 F.R.D. 218, 223-24 (D. Md. 1955). The standard referred to was promulgated in Wuchter v. Pizzutti, 276 U.S.13 (1928): "[T] he act of a nonresident in using the highways of another state may properly be declared to be an agreement to accept service of summons in a suit growing out of the use of the highway by the owner of the automobile, but the enforced acceptance of the service of process on a state officer by the defendant would not be fair or due process unless such officer or the plaintiff is required to mail the notice to the defendant, or ... make it reasonably probable that he will receive actual notice." Many cases have used reasoning similar to that employed in Holbrook in holding that Rule 4 (d)( 7 ) authorizes substituted service on a state official followed by transmission of notice to the defendant. See, e.g., Pasternack v. Dalo, 17 F.R.D. 420 (W.D. Pa. 1955); Giffin v. Ensign, 15 F.R.D. 200 (M.D. Pa1953); Moon v. Makowski, 114 F. Supp. 914 (S.D. Ohio 1953). In Giffin v. Ensign, 234 F.2d 307, 311 (3rd Cir. 1956), however, the Third Circuit reached the same result without seeming to place much reliance on the substituted service feature of the state statute there involved.

' Wis. STAT. ANN. $\S 262.09$ (4) (1957). "If the defendant is a foreign corporation ... and ... (b) the cause of action against it arose out of the doing of business in Wisconsin, service may be made ... by delivering within or without the state a copy of the summons to any officer, director, or managing agent of the corporation."

${ }^{10} \mathrm{It}$ is true, of course, that extraterritorial service is never upheld where there is no federal or state statute so authorizing. Hanes Supply Co. v. Valley Evaporating Co., 261 F.2d 29 (5th Cir. 1958); Hagan v. Central Avenue Dairy, 180 F.2d 502 (9th Cir. 1950); Hygeia Dairy v. Benson, 151 F.Supp. 661 (S.D. Tex. 1957); McDaniel v. Drotman, 103 F. Supp.643 (W.D. Ky. 1952); Miller v. Hano, 8 F.R.D. 67 (E.D. Pa. 1957).

11 It is the duty of the courts to prevent separate parts of a statute from being mutually restrictive. Federal Power Commission v. Panhandle Eastern Pipeline Co., 337 U.S. 498 (1949); International Rice Milling Co. v. NLRB, 183 F.2d 21(5th Cir. 1950), rev'd. on other grounds, 341 U.S. 665 (1951); Dealer's Transport Co. v. Reese, 138 F.2d 638 (5th Cir. 1943). The parts 
own sphere of influence. The proposition is advanced that Rule 4(d)(7) permits use only of statutes which determine the manner and mode of service, not those allowing extraterritorial service. Rule 4(f), on the other hand, is purportedly an absolute prohibition against out-of-state service. It must be remembered in this context that the courts in construing the Rules have the duty of giving "full expression to the meaning of the words used without one rule modifying another."12

The Kappzs argument points out that $4(\mathrm{~d})(7)$ and $4(\mathrm{f})$ were meant to be applicable to different facets of the same procedure, i.e., service of process. Rule 4(f) was intended to permit a district court to extend its service to the entire state in which it was sitting. Previously such service had been permitted only within the district. Rule $4(f)$, it is argued, was intended to have no effect whatever on 4 (d)(7)..$^{13}$ It would seem that an interpretation of the Rules under which $4(\mathrm{~d})(7)$ is limited by $4(\mathrm{f})$ not only overly restricts the natural meaning of the words of $4(\mathrm{~d})(7)$, but at the same time ignores the very language of $4(f)$. Rule $4(d)(7)$ is presently excluded from the purview of $4(f)$ by the exception that extraterritorial service may be made "when a statute of the United States so provides...."14 The Federal Rules, while not having complete statutory power, closely approximate that authority. Indeed, a number of cases have attributed the complete efficacy of statutes to the Federal Rules. ${ }^{15}$ If Rule $4(d)(7)$ were regarded as a "statute" within the meaning of $4(f)$, there would be no doubt that the Kappus interpretation is correct and the two rules would be entirely consistent. However, the Advisory Committee for the Federal Rules of Civil Procedure has proposed an amendment to Rule 4(f) which might be said to lead to the opposite conclusion. This new rule would provide that: "All process other than a subpoena may be served anywhere within the territorial limits of the state in which the district court is held, and when a statute of the United States or these rules so provide, beyond the territorial

should, as far as is possible, be harmonized with each other and with the general intent of the lawmaking body. Fleischmann Const. Co. v. United States ex. rel. Forsberg, 270 U.S. 349 (1926); Iglehart v. Iglehart, 204 U.S. 478 (1907). Toward this end, it has of ten been held that the Federal Rules are to be considered as being in pari materia. Panamusica Venezuela C.A. v. American Steel Export Co., 16 F.R.D. 280 (S.D. N.Y. 1954); North v. Lehigh Valley Transit Co., 10 F.R.D. 38 (E.D. Pa. 1950); Agricultural Lands, Inc. v. Panhandle \& S.F.Ry., 60 F. Supp. 108 (W.D. Mo. 1945).

12. Westland Oil Co. v. Firestone Tire \& Rubber Co., 3 F.R.D. 55, 56 (D. N.Dak. 1943).

${ }_{13}$ "We think that it can be said fairly that Rule $4(f)$ does not address itself to or cover nonresident procedures authorized by State law, which are the subject of Rule 4(d)(7). That conclusion, and no more, is needed to decide this case. The service was lawful." Giffin v. Ensign, 234 F.2d 307, 311 (3rd Cir. 1956).

14 Fed. R. Civ. P. 4(f).

15 Sinsor v. Daumit, 179 F.2d 475 (7th Cir. 1950); John R. Alley \& Co. v. Federal National Bank, 124 F.2d 995 (10th Cir. 1942). Beasley v. United States, 81 F. Supp. 518 (E.D. S.C. 1948); Nash v. Raun, 67 F. Supp. 212 (W.D. Pa. 1946); 
limits of the state."16 (New portion in italics.) It can be argued that the proposed amendment represents an implicit admission that the term "statute" does not embrace the Federal Rules as Rule 4(f) is presently worded. By specifically differentiating between "statute" and "rules" the .Committee confesses that $4(d)(7)$ is currently inadequate to overcome the prohibition placed upon service beyond state lines by Rule $4(f)$. But a more powerful argument may be made for the alternative: the new rule is meant to be nothing more than a clarification of the original formulation of the drafters, which has been misconstrued by many federal courts. ${ }^{17}$ This position makes possible the avoidance of difficulties arising out of the application of the pari materia principle, since it is only in this fashion that the two rules can be fully reconciled.

The Advisory Committee adopts the Kappus interpretation as the proper one. In commenting upon the amendment, it says that the doctrine of restriction "prevents use of this convenient means [nonresident motorist statutes] for suing at the place where the accident occurred." 18 The Committee's stand is more clearly defined by the comments upon an almost identical amendment to Rule 4(e):19 "It [the amendment] will remove doubt and allay confusion to permit suits in the diversity jurisdiction" to proceed "in conformity with state practice. ..."20 (Emphasis supplied.) Yet certain as its stand is upon this matter, the Committee neglects to refute many of the arguments advanced by the proponents of the thesis that 4(f) limits the operation of $4(\mathrm{~d})(7)$.

A major advantage seen by the advocates of the restrictive interpretation is that under this interpretation fewer cases are brought in the federal district courts under the diversity jurisdiction. ${ }^{21}$ It has become evident that the reasons for originally conferring diversity jurisdiction on the federal courts are not as compelling as they once were. The clear superiority of the federal courts in both procedure and quality of the bench is rapidly disappearing. Moreover,

16 Advisory Colamittee Report of Proposed Amendments to the Rules of Civil Procedure 10-12 (1955) (hereinafter cited as AdvisoRy CoMar. ReP.).

17 "In 1938 [the year in which the Federal Rules became effective] there were at least forty State statutes affecting nonresident motorists; and it seems almost inescapable that if Rule 4(f) was intended to override Rule 4(d)(7) some discussion would have been had on such an important change." Gifin v. Ensign, 234 F.2d 307, 312 n.4 (3rd Cir. 1956).

18 Advisory Comar. Rep., 12.

19 "Whenever a statute of the United States or these rules provides for service of summons, or of a notice, or of an order in lieu of summons upon a party not an inhabitant of or found within the state, service shall be made under the circumstances and in the manner prescribed by the statute, rule, or order. Whenever a statute or rule of coutt of the state in which the district court is held provides for notice to such a party to appear and respond to or defend in an action by reason of the athachment or garnishment of his property located within the shate, or for service of a summons, notice, or order in lieu of summons upon a party not an inhabitant of or found within the state, it shall also be sufficient if service is made or the party is brought before the coutt under the circumstances and in the manner prescribed in the state statutes or rules." (New portion in italics.)

${ }^{20}$ Advisory Cosnr. ReP., 8-9.

${ }^{21}$ It has been estimated that between thirty and thirty-seven percent of all diversity cases involve automobile accidents. Doub, Time for Re-Evaluation: Shall We Curtail Diversity Jurisdiction?, 44 A.B.A.J. 243, 278 (1958). 
maintaining a suit in the federal system is often more expensive than maintaining it in the state courts. ${ }^{22}$

Insofar as limiting the business of the federal courts is an unarticulated consideration in the minds of those judges adopting the prohibitive theory of $4(f)$, it would appear that they have fallen into the error of legislating by judicial fiat. It is for Congress alone to promulgate measures curtailing the jurisdiction of the federal courts. ${ }^{23}$ The increase in number of diversity cases resulting from the use of $4(\mathrm{~d})(7)$ exemplified in Kappus would seem to be the result of legislative intent, and the courts are in no position to bring about a contrary result. ${ }^{24}$

= See generally, Kurland, Mr. Justice Frankfurter, The Supreme Court and the Erie Doctrine in Diversily Cases, 67 YALE L.J. 187, 195-97 (1957). Professor Kurland concludes that while the federal courts "offer juries chosen from a broader geographical base and, generally, from a group of higher economic and social status, ... none of these considerations seems to justify the existence of diversity jurisdiction in our federal system today." Id. at 197.

"In my opinion the greatest contribution that Congress could make to the orderly administration of justice in the United States would be to abolish the jurisdiction of the federal courts which is based solely on the ground that the litigants are citizens of different states." Jackson, The Supreje Court in the American System of Government 38 (1955). For a defense of the diversity jurisdiction, see Parker, Dual Sovereignty and the Federal Courts, 51 Nw. L. REv، 407, 409 (1956).

${ }^{23}$ There have been indications that Congress intends to do just that. "[A] corporation shall be deemed a citizen of any State by which it has been incorporated and of the State where it has its principal place of business." 28 U.S.C.A. $\$ 1332$ (c) (1958).

21 Ignoring the 4(d)(7)-4(f) conflict altogether, some courts have gone so far as to apply Erie R.R. v. Tompkins, 304 U.S. 64 (1938), to the solution of the problem. Substance and procedure being the inexact categories that they are, it is not extraordinary that a number of courts have sought to apply Erie to uphold extraterritorial service. They admit thereby that they consider service of process to be substantive. See Clark, The Tompkins Case and the Federal Rules, 1 F.R.D. 417 (1940). However, while there are cases which have held some of the Federal Rules substantive, it is believed that service of process should be classified as procedural. Ragan v. Merchants Transfer Co., 337 U.S. 530 (1949) held Rule 3 substantive. See also Cohen v. Beneficial Industrial Loan Corp., 337 U.S. 541 (1949). But cf. Byrd v. Blue Ridge Elec. Corp., 356 U.S. 525 (1958). For cases classifying the Federal Rules as procedural, see Whitaker \& Co. v. Sewer Improvement Dist. No. 1, 221 F.2d 649 (8th Cir. 1955); Occidental Life Ins. Co. of California v. Kielhorn, 98 F.Supp. 288 (W.D. Mich. 1951); Kuper v. Johns, 94 F.Supp. 305 (S.D. W.Va. 1950). If service of process were considered substantive, Erie would apply, and the federal courts would become obligated to use the state statutes. If this were the case, there would be no need for $4(d)(7)$, since the function it purports to perform could be effected without it. In that situation, it would have been seen that 4 (d)(7) was superfluous, and it would have been eliminated by now. It would be contrary to long standing precedent were service of process to be labelled substantive at this late date.

Another fault to be found with the use of Erie becomes manifest when the essential nature of the $4(\mathrm{~d})(7)$ problem is considered. Rule $4(\mathrm{f})$ states that extraterritorial service may be made only "when a statute of the United States so provides. ..." We can assume, for these purposes, that either 4(d)(7) fulfills this requirement or it does not, and that its application will stand or fall upon the ultimate resolution of this problem. If it is a "statute," Erie becomes unnecessary. If it is not, by what manner can case law succeed where a quasi-statute, more authoritative, cannot?

Notwithstanding, a number of cases have used Erie. "By driving on the highways of the State of Illinois, a nonresident driver is submitting himself to the laws of the State of Illinois and is making himself amenable to personal service of summons.... This amenableness to personal service of summons extends to any court sitting in the State which applies the law of the State and when a federal court in a diversity case applies the substantive law of the 
The notion of expanding the number of cases in the diversity jurisdiction should not be confused with an expansion of that jurisdiction itself. Rule 4(d)(7), when used to permit extraterritorial service, might be thought to abridge the substantive rights of defendants. But closer analysis shows that this is not the case. It has been feared that 4 (d)( 7 ) could be used to overcome venue requirements. ${ }^{25}$ In $M c$ Coy v. Siler, ${ }_{2}^{26}$ however, it was the opinion of the court that the defendant, by driving upon the highways of another state, did not waive the federal venue provisions. Suit had to be maintained in the district where all the plaintiffs or all the defendants resided; the venue statute did not give way to $4(\mathrm{~d})(7) .{ }^{27}$ Similarly, it has been thought that 4 (d)(7) infringes upon the substantive rights of the defendant in subjecting him to the jurisdiction of a court to which he previously could not have been summoned. This contention ignores the fact that the Rule is merely "a kind of catchall, providing that in classes (1) and (3) above-that is, those dealing with the individual or the corporation or association-any form of service which would be good in the State where the district court is sitting shall also be held good in the federal court."28 Its justification was convenience, not expansion of jurisdiction.

Nor does Rule 4(f) expand either jurisdiction or venue. Its purpose was to expand, rather, the present rule as to where service may be made. As was concluded by the Supreme Court: "Rule 4(f) serves only to implement the jurisdiction over the subject matter which Congress has conferred, by providing a procedure by which the defendant may be brought into court at a place where Congress has declared that the suit may be maintained." ${ }^{29}$ It would seem

State in which it sits, it is just another State court insofar as that suit is concerned." Star v. Rogalny, 162 F.Supp. 181, 184 (E.D. Ill. 1957). But see Taylor v. Reading Co., 23 F.R.D. 186 (E.D. Pa. 1958); B-Amused Co. v. Melrose Sporting Club, Inc., 168 F.Supp. 709 (E.D. N.Y. 1958); Rensing v. Turner Aviation Corp., 166 F. Supp. 790 (N.D. Ill. 1958).

${ }^{25} 28$ U.S.C. $\$ 1391$ (a) (1958). "A Civil action wherein jurisdiction is founded only on diversity of citizenship may ... be brought only in the judicial district where all plaintiffs or all defendants reside."

${ }^{26} 205$ F.2d 498 (3rd Cir. 1953).

${ }^{27}$ This view was subsequently affirmed in Olberding v. Illinois Cent. R.R., 346 U.S. 338 (1953). A number of cases have held that the appointment of an agent for service of process by drivers on state highways was a waiver of federal venue rights. E.g., Falter v. Southwest Wheel Co., 109 F. Supp. 556 (W.D. Pa. 1953); Archambeau v. Emerson, 108 F. Supp. 28 (W.D. Mich. 1952); Jacobson v. Schumann, 105 F. Supp. 483 (D. Vt. 1952).

${ }^{28}$ Federal Rules of Civil Procedure and Proceedings of the American Bar Association Institute at 205 (1938).

${ }^{29}$ Mississippi Publishing Co. v. Murphree, 326 U.S. 438, 445 (1946). Earlier lower court decisions had recognized that Rule 4(f) did not result in a substantive expansion of jurisdiction. Gilbert v. Gulf Oil Co., 153 F.2d 883 (2d Cir. 1946); Schwartz v. Artcraft Silk Hosiery Mills, 110 F.2d 465 (2d Cir. 1940); O'Leary v. Loften, 3 F.R.D. 36 (E.D. N.Y. 1942); Williams v. James, 34 F.Supp. 61 (W.D. La. 1940); Devier v. George Cole Motor Co., 27 F. Supp. 978 (W.D. Va. 1939). Contra: Gibbs v. Emerson Electric Mfg. Co., 35 F. Supp. 213 (W.D. Mo. 1940); Carby v. Greco, 31 F. Supp. 251 (W.D. Ky. 1940); Melekov v. Collins, 30 F. Supp. 1.59 (S.D. Calif. 1939). 
strange that a rule meant to "implement" jurisdiction should be employed to restrict the "implementation" afforded by Rule 4(d)(7).

A distinct problem exists concerning the "federal question" jurisdiction of the federal courts. ${ }^{30}$ If $4($ d)(7) authorizes out-of-state service, it would appear that state statutes are being used to implement enforcement of federally created rights. The ability of the federal courts to subject the defendant to jurisdiction would seem to vary from state to state, depending upon the statute employed. However, in practice this variance would be slight. The extraterritorial service of process statutes vary remarkably little from state to state. It is difficult to imagine a situation in which a plaintiff might be prohibited from obtaining jurisdiction over the defendant solely because of a variance in the state statute. In addition, Section 1404(a) of the Judiciary Act ${ }^{31}$ would serve to protect the defendant from any severe injustice resulting from being served extraterritorially, since the suit would be transferred to a more convenient forum if the circumstances required it. Whatever variance there is would appear to bring about a situation resembling that which existed under the Conformity Act. ${ }^{32}$ This act provided that, outside of equity and admiralty cases, federal practice had to conform as nearly as possible to the practice of the state in which the district court was sitting. The result was general confusion and a complete lack of uniformity in the procedures of the various federal courts. It was to achieve a single procedural standard that the Federal Rules were promulgated.

Nevertheless, 4(d)(7) appears to be an exception to the otherwise consistent desire to escape the disorder generated by the Conformity Act. Four (d)(7) specifically allows use of state statutes. In the area of service of process, Congress has manifested an intent to permit the courts to proceed in this manner. Here again the proposition that the courts perforce must abide by legislative intent appears controlling. It would seem then, that all arguments based upon the case law, upon the intent of the drafters, and upon the intention of Congress in permitting the Rules to become law must be resolved in favor of the Kappus construction. Furthermore, a number of subordinate considerations argue for the broad resolution of the conflict.

Constricting 4(d)(7) would severely affect the scope of a number of Federal Rules. Foremost would be the effect upon Rule 14. The purpose of this Rule-to avoid circuity and multiplicity of action through the joinder of third partieswould be frustrated if the party seeking the joinder were forbidden to do so

${ }^{30}$ The magnitude of the problem is not as great here, since many federal statutes carry with them their own service of process provisions. E.g., Declaratory Judgment Act, 28 U.S.C. $\$ \S 2201-02$ (1958); Federal Interpleader Act., 28 U.S.C. $\$ \S 1335,1397,2361$ (1958); Bankruptcy Act, 11 U.S.C. $\$ \S 501,1011$ (1958). See In re Clarke, 35 F. Supp. 227 (S.D. N.Y. 1940); United States v. United States Freight Co., 80 F.Supp. 336 (S.D.N.Y. 1947). Nevertheless, "the situation is analogous to that in cases where federal court jurisdiction is based upon diversity of citizenship." Van Wie v. United States, 77 F. Supp. 22, 40 (N.D. Iowa 1948).

31 28 U.S.C. $\$ 1404$ (a) (1958).

17 Stat. 197 (1872). 
unless the third party defendant happened to live within the state in which suit were being brought. The restrictive interpretation of 4 (d)(7) would have a similar effect on the operation of Rule 19, which provides for necessary joinder. Since indispensable parties could not be joined unless they could be served in the state of the suit, an increased number of actions would be dismissed pursuant to Rule 12(b) for failure to join all indispensable parties. Rule 22(1) permits the interpleading of parties so as to prevent the holder of funds from being exposed to double liability. Restrictions on out-of-state service would quite obviously minimize the usefulness of this Rule in avoiding double liability. ${ }^{33}$ These collateral effects of the restrictive interpretation of $4(d)(7)$ are far reaching and militate for disavowance of this interpretation.

Finally, considerations of providing for a just trial warrant acceptance of the broad application of 4 (d)(7). The suit could then be filed in a convenient forum-the state in which the cause of action arose. It is there that evidence and witnesses are most conveniently available. The injured person is spared the expense of travelling to the district of the nonresident defendant. When a nonresident drives upon the highways of another state and becomes involved in an accident, the obligation to return for suit is not an undue burden. ${ }^{34}$

\footnotetext{
${ }^{33}$ In addition to rule interpleader, provided for by Rule $22(1)$, there exists a statutory interpleader action created by 28 U.S.C. $\$ \$ 1335,1397,2361$ (1958), and acknowledged in Rule 22(2). The interpretation given Rules $4(d)(7)$ and $4(f)$ would only affect service of process in rule interpleader proceedings since nationwide service is provided for in statutory interpleader actions. 28 U.S.C. $\$ 2361$ (1958).

${ }^{31}$ In addition it has been pointed out that the delay in the state courts is a major factor to be taken into consideration. "For example, the trial courts in Cook County, Illinois, are presently some four to five years behind on their trial calendars. To place the additional burden on them of handling the cases which are now filed in the federal court under diversity jurisdiction would be to cause a breakdown of the Illinois judicial system." Kurland, supra note 22 , at 197 n.52.
}

\section{THE DEFENSE OF ANTITRUST ILLEGALITY IN CONTRACT ACTIONS}

In 1958, the Supreme Court, in Kelly v. Kosuga, ${ }^{1}$ restated its standards for recognition of the defense of antitrust illegality to an action brought to enforce a contract. That case, together with two subsequent cases decided by the Sixth and Seventh Circuit Courts of Appeals, ${ }^{2}$ indicates the need for a reexamination of the traditional doctrines ${ }^{3}$ and the possibility that a formulation may be

1358 U.S. 516 (1959).

2 Beloit Culligan Soft Water Service, Inc. v. Culligan, Inc., 274 F.2d 29 (7th Cir. 1959); Tampa Elec. Co. v. Nashville Coal Co., 276 F.2d 766 (6th Cir. 1960).

3 The basic rule is that the courts will refuse absolutely to enforce illegal contracts. The harshness of this rule, if rigidly applied, has led to the creation of a number of exceptions. Three major exceptions are (1) contracts which are only "collaterally" illegal, (2) contracts in which the illegal portion is sufficiently independent to be deemed severable, and (3) contracts where the plaintiff is not in pari delicto with the defendant. Such contracts may be enforced 